\title{
Characterization of Niacin of Skipjack Tuna Muscle and Change of the Niacin Content during Storage
}

\author{
Watanabe Fumino*, Goto Masahiro*, \\ Abe Katsuo* and Nakano Yoshihisa*
}

\begin{abstract}
*Department of Food and Nutrition, Kochi Women's University, Kochi 780, ${ }^{* *}$ Department of Applied Biological Chemistry, Osaka Perfecture University, Sakai, Osaka 593.
\end{abstract}

Niacin content in the upper and lower ordinary muscles $(0.91 \pm 0.06-0.93 \pm 0.05 \mathrm{mmol} /$ total tissues) of skipjack tuna showed a much higher level than in the liver or dark muscle. Most $(98.4 \pm 0.8 \%)$ of the niacin was free form, and not bound to protein in the tuna muscle. The amount of the coenzyme forms of niacin, NAD $(\mathrm{H})$ and NADP $(\mathrm{H})$, was scarcely contained in the tuna muscle. The muscle niacin of skipjack tuna was not lost during storage at $4^{\circ} \mathrm{C}$ for 5 days. These results indicate that the tuna ordinary muscle is an important dietary source of niacin.

(Received Mar. 22, 1996)

\section{INTRODUCTION}

Fish is an important source of easily digestible proteins, and contains many essential nutrients ${ }^{1)}$. Especially, tuna is an excellent "food fish", and readily available. Among fishes, tuna (edible portion) contains the highest amount of niacin ${ }^{2}$, of which a deficiency of is well known to lead to the human disease, pellagra ${ }^{3)}$. Niacin ingested is converted to two related coenzymes, NAD $(\mathrm{H})$ and NADP $(\mathrm{H})$, for the enzymes catalyzing reaction of oxidation or reduction in cellular metabolism ${ }^{3}$. It has been reported that the mean dietary intake of niacin decreases considerably in elderly people than the Recommended Dietary Allowance $(15 \mathrm{mg})^{4)}$. Thus, tuna would be an important dietary source of niacin.

Although different species of tuna are found, we used skipjack tuna in the experiments because very fresh skipjack tuna is easily available at our local fish market. To characterize niacin of skipjack tuna, niacin was assayed in the tuna muscles and liver, and change in the niacin content of the tuna fillets during storage was also determined.

\section{Materials and Methods}

\section{Materials}

Fresh skipjack tuna (Euthynnus pelamis) was obtained from a local fish market in Kochi-City, Japan. The muscles (ordinary and dark muscles) and livers from three fishes of skipjack tuna (body weight $2.2 \pm 0.3 \mathrm{~kg}$ ) which were caught off of Tosa-shimizu, Kochi, in spring, were used.

Nicotinic acid, NAD and NADP, were obtained from Wako Pure Chemical Industries, Osaka, Japan. Yeast alcohol dehydrogenase (EC 1.1.1.1) and glucose-6-phosphate dehydrogenase (EC 1.1.1.49) were obtained from Oriental Yeast Co., Ltd, Kyoto, Japan. All other reagents used were of the highest purity commercially available.

\section{Assay of niacin}

Fillet of skipjack tuna was divided into three parts, upper and lower ordinary muscles, and dark 
muscle. One $\mathrm{g}$ of each muscles or liver was homogenized in 5 volumes of distilled water at room temperature using a universal homogenizer (Nihon Seiki Seisakusho Co., Tokyo, Japan). $\mathrm{KOH}$ was added to the homogenate in the final concentration of $1 \mathrm{M}$ and then niacin was extracted for $1 \mathrm{~h}$ in an autoclave. The extract was cooled into water bath, neutralized by the addition of $5 \mathrm{M} \mathrm{HCl}$ and then centrifuged at 5000 $\mathrm{x} g$ for $10 \mathrm{~min}$. The supernatant was used in the assay of niacin. Niacin was assayed spectrophotometrically by the cyanogen bromide method of Bellion ${ }^{5}$. Nicotinic acid was used as a standard.

\section{Assay of NAD $(\mathrm{H})$ and NADP $(\mathrm{H})$}

$\mathrm{NAD}(\mathrm{H})$ and NADP $(\mathrm{H})$ were assyed by the enzyme- (alcohol dehydrogenase and glucose-6phosphate dehydrogenase, respectively) -cycling method of Nisselbaum and Green ${ }^{6}$. Ten $\mathrm{g}$ of skipjack tuna muscle was homogenized in 5 volumes of $50 \mathrm{mM}$ potassium phosphate buffer, $\mathrm{pH} 6.0$, containing $100 \mathrm{mM}$ niconinamide at $4^{\circ} \mathrm{C}$ using the universal homogenizer, and then centrifuged at $500 \times \mathrm{g}$ for $10 \mathrm{~min}$ at $2^{\circ} \mathrm{C}$. The supernatant was used as a sample.

Assay of niacin-binding protein

Niacin-binding protein was determined by a gel filtration method as follows. Ten $\mathrm{g}$ of skipjack tuna muscle was homogenized in 5 volumes of 10 $\mathrm{mM}$ potassium phosphate buffer, $\mathrm{pH} 7.0$, at $4^{\circ} \mathrm{C}$ using a universal homogenizer, and centrifuged at $10,000 \times g$ for $10 \mathrm{~min}$ at $2^{\circ} \mathrm{C}$. A portion $(1 \mathrm{ml})$ of the supernatant was put on a pre-packed gel filtration column, Econopack ${ }^{\mathrm{TM}}$ 10DG (Bio-Rad Laboratories), which was equilibrated with 10 $\mathrm{mM}$ potassium phosphate buffer, $\mathrm{pH}$ 7.0, containing $100 \mathrm{mM} \mathrm{KCl}$. The niacin bound to protein was eluted with $4 \mathrm{ml}$ of the same buffer and then free niacin was further eluted with $10 \mathrm{ml}$ of the same buffer. Niacin was extracted and assayed in the fractions.

\section{Storage experiments}

The fillets prepared from skipjack tuna were packed into polyethylene bags and kept at $4^{\circ} \mathrm{C}$ for 5 days in a refrigerator. At the indicated times, niacin was extracted and assayed in the fillets.

\section{Statistics}

Statistical significance was determined using Student's $t$-test; $p<0.01$ was considered significant. All values are presented as mean \pm SD.

\section{Results and Discussion}

\section{Total niacin content}

Niacin was assayed in the upper and lower

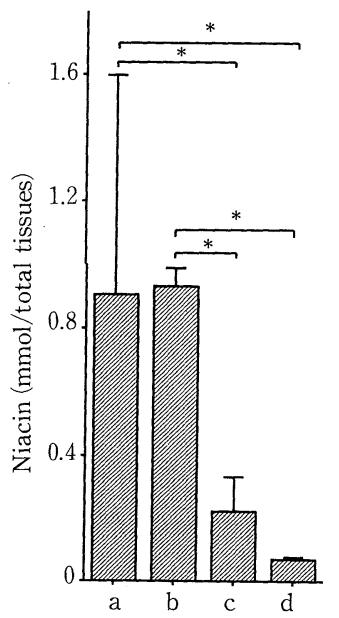

Fig. 1 Niacin content per total tissue of the muscles and liver of skipjack tuna: (a), upper ordinary muscle; (b), lower ordinary muscle; (c), dark muscle; (d), liver. Data represent mean $\pm S D$; $n=3$.

ordinary muscles, dark muscle and liver of fresh skipjack tuna. A similar level of niacin (1.33土 $0.32-1.70 \pm 0.86 \mu \mathrm{mol} / \mathrm{g}$ tissues) was found in $1 \mathrm{~g}$ of each tissue. Total niacin content in the upper and lower ordinary muscles $(0.91 \pm 0.06-0.93 \pm$ $0.05 \mathrm{mmol} /$ total tissues) showed much higher level than in the liver or dark muscle (Fig. 1). These results indicate that the ordinary muscles of skipjack tuna contain a substantial amount of niacin. About $60 \mathrm{~g}$ of the edible portion (ordinary and dark muscles) of skipjack tuna $(2.13 \pm 0.60$ $\mu \mathrm{mol} / \mathrm{g}$ tissues) contained niacin equivalent to the Recommended Dietary Allowance.

\section{Niacin-binding protein}

To determine whether niacin-binding protein occurs in the muscle of skipjack tuna, a gel filtration experiment was conducted. Most 
$(98.4 \pm 0.8 \%)$ of the niacin found in the tuna muscle homogenate was free form, but only a small amount $(1.6 \pm 0.4 \%)$ of niacin was bound to protein. These results indicate that free niacin is accumulated in the cells of the tuna muscle.

\section{Coenzyme forms of niacin}

The coenzyme forms of niacin were assayed in the muscle (ordinary and dark muscles) of skipjack tuna. The tuna muscle contained only a trace amount of the coenzymes $(\mathrm{NAD}(\mathrm{H})$; $0.13 \pm 0.06 \mathrm{nmol} / \mathrm{g}$ tissues and $\mathrm{NADP}(\mathrm{H})$; trace) . The muscle coenzymes may be immediately

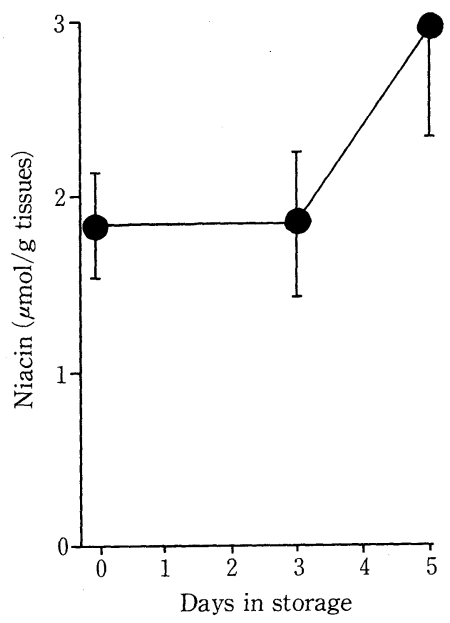

Fig. 2 Changes in niacin content of skipjack tuna muscle during storage. Data represent mean $\pm \mathrm{SD}$; $\mathrm{n}=3$.

converted to niacin after the death of the fish, since the coenzymes predominate in living cells ${ }^{3)}$. Mammalian liver has been reported to contain considerable amounts of $\mathrm{NAD}(\mathrm{H})(531 \pm 29 \mu \mathrm{g} / \mathrm{g}$ tissues) and $\mathrm{NADP}(\mathrm{H})(223 \pm 32 \mu \mathrm{g} / \mathrm{g} \text { tissues })^{6)}$. These observations suggest that $\mathrm{NAD}^{+}$(EC 3.2.2.5) or $\mathrm{NADP}^{+}$(EC 3.2.2.6) nucleosidase (or both), which catalyzes the conversion of NAD
$(\mathrm{P})^{+}$to nicotinamide and ADP-ribose, occurs in the tuna muscle.

\section{Effect of storage}

Changes in niacin content during storage of the tuna fillet at $4^{\circ} \mathrm{C}$ was determined (Fig. 2). The niacin content did not change up to 3 days and increased slightly thereafter. Although the increase of niacin content in the 5-day-storage tuna muscle was not significant, we had little information available on why there is such an increase in niacin content during storage. The results indicate that muscle niacin of skipjack tuna is not lost during storage.

These results indicate that the ordinary tuna muscle is an important dietary source of niacin.

\section{ACKNOWLEDGMENTS}

We thank Miss Kazumi Yokoyama for technical assistance.

\section{RENREFECES}

1) Bissell, F.: The Book of Food, Henry Holt and Company Inc., New York, pp. 146 168 (1991).

2) Gebhardt, S. E. and Matthews, R. H.: Nutritive Value of Foods, United States Department of Agriculture, Human Nutrition Information Service, Home and Garden Bulletin Number 72, pp. 18 19 (1991).

3) JACOB, R. A. and SwendSeID, M. E.: Present Knowledge in Nutrition, 6th ed., ed. by Brown, M. L, International Life Science Institute-Nutrition Foundation, Washigton D. C., pp. 163 169 (1990).

$4)$ Russell, R. M. and Suter, P. M.: Am. J. Clin. Nutr., 58, 4 (1993).

5) Bellion, E.: Anal. Biochem. 25, 578 (1968).

6) Nisselbaum, J. S. and Green, S.: Anal. Biochem. , 27, 212 (1969). 
鰹肉の低温貯蔵におけるナイアシン含有量の変化 渡辺文雄*. 後藤昌弘 ${ }^{*}$. 阿部捷男*. 中野長久 ${ }^{* *}$ $*$ 高知女子大学家政学部食物栄養学科

( T780 高知県高知市永国寺町5-15)

* * 大阪府立大学農学部応用生物化学科

( ( 593 大阪府堺市学園町1-1)

鰹肉は水分含有量が比較的低く，肉質が筋肉質で あり，旨味成分を多量に含むため，味が濃厚である。 また，栄養面ではタンパク質，リン，鉄，ビタミン $\mathrm{B}_{2}$ およびナイアシンを多く含んでいる。特に,十イ アシンは可食部 $100 \mathrm{~g}$ あたり $19 \mathrm{mg}$ と, 生鮮食品中でも 最も多い。そこで，このナイアシンが鏗肉のどの部 位に多く含有されているのか，またどのような形態 で存在しているのかを明らかにし, 鰹肉の低温貯蔵 におけるナイアシン含有量の変化について検討した。 鰹各組織からナイアシンをアルカリ抽出し, 中和後,
遠心分離上澄み画分を試料とした。ナイアシンの定 量はブロムシアン法を用いて行った。また, 補䤉素 型ナイアシンの定量はアルコールデヒドロゲナーゼ とグルコースー6ーリン酸デヒドロゲナーゼによる 酵素サイクリング法を用いた。その結果, 組織 $1 \mathrm{~g}$ あたりに含まれるナイアシン含有量は各組織でほと んど変化なかったが, 組織全体でのナイアシン含有 量は背肉と腹肉で最も高かった。鰹肉のナイアシン のほとんどは遊離の状態で存在しており, タンパク 質と結合していなかった。また, 鰹肉には補酵素型 ナイアシン $(\mathrm{NAD}(\mathrm{H})$ と $\mathrm{NADP}(\mathrm{H}))$ がほとんど含 まれていなかった。鰹肉切り身を $4{ }^{\circ} \mathrm{C} て ゙ 5$ 日間貯蔵 を行った結果, 鰹肉ナイアシン含有量は 5 日目で若 干の増加傾向が示されたが有意なものではなかった。 この結果鰹肉ナイアシンは低温貯蔵においてまった く損失がないことが明らかとなった。

(平成 8 年 3 月 26 日受理) 